\title{
CHARACTERIZATION OF AROMA-ACTIVE COMPOUNDS IN BLACK SAPOTE (DIOSPYROS DIGYNA JACQ.)
}

\author{
J.A. Pino ${ }^{a}$, E. Ortiz-Vazquez ${ }^{b}$, E. SAuri-Duch ${ }^{\text {b }}$ and L. Cuevas-Glory ${ }^{b *}$ \\ ${ }^{a}$ Food Industry Research Institute, Carretera al Guatao km 31⁄2, La Habana, C.P. 19200. Cuba \\ binstituto Tecnológico de Mérida, Ave. Tecnológico km 41⁄2, Mérida, Yucatán, CP 97118. México.
}

(Received: 30 August 2012; accepted: 17 November 2012)

\begin{abstract}
The volatile compounds of black sapote fruit were isolated by simultaneous distillation-solvent extraction and analysed by gas chromatography-flame ionization detector and gas chromatography-mass spectrometry. A total of 32 volatile constituents were detected, which represented $4.57 \mathrm{mg} \mathrm{kg}^{-1}$ of the fruit. The composition of volatile constituents of the fruit included 9 terpene compounds ( $49.1 \%$ of the total volatile composition), 11 ketones ( $9 \%), 5$ aldehydes (29.2\%), 4 alcohols (3.6\%), 2 esters $(8.2 \%)$ and a paraffin $(0.8 \%)$. Major compounds were $(Z)$-b-ocimene (26.6\% of the total volatile composition), $(E)$-cinnamaldehyde $(25.5 \%)$ and limonene $(17.0 \%)$. By application of odour activity values, seven constituents were considered as aroma-active volatiles, from which the most important were (E)-cinnamaldehyde, 3-methylbutanal, limonene, (Z)- $\beta$-ocimene, linalool, methyl $(E)$-cinnamate, and $\beta$-caryophyllene.
\end{abstract}

Keywords: black sapote, Diospyros digyna, aroma-active compounds, gas chromatography-mass spectrometry

The black sapote (Diospyros digyna Jacq.) is a fruit native to Southern Mexico and Central America that belongs to the family of Ebenaceae, as does the persimmon (Diospyros kaki) and the ebony (Diospyros ebenum) (MARTín et al., 1987). In Mexico this species is found in diverse tropical and subtropical zones. In 2001, the production of black sapote was 729.2 ton, produced principally in the States of Tabasco, Guerrero, Chiapas and Puebla (SAGARPA, 2001). The fruit is a globe-shaped berry with a persistent calyx with a diameter of 7 to $12 \mathrm{~cm}$; the epicarp is bright green at physiological ripeness and is adhered to the pulp; the mesocarp is brown to black, very abundant and sweet, containing 6 to 10 seeds per fruit, encased in a transparent membrane (Morton, 1987; MARTín et al., 1987). The black sapote contains mainly carbohydrates, minerals, and ascorbic acid. The ascorbic acid content in black sapote fruit is higher than in citrus fruits (MILLER et al., 1998). Due to its organoleptic characteristics, the fruit is consumed while fresh; the pulp is used in the elaboration of ice cream and popsicles, for filling in desserts, and in the making of preserves (Miller et al., 1998). The unripe fruit have a golden yellow coloured pulp and are not edible due to its highly astringent taste; when ripe, the pulp becomes completely soft and with a characteristic brown to black colour (LEDESMA \& CAMPBELL, 2001). Despite its wide acceptance in diverse regional markets and its great potential for commercialization as an exotic fruit, information available regarding the aroma of this fruit is practically nonexistent. Thus, the objective of the present study was to analyse the volatile compounds that generate the aroma of black sapote fruit.

\footnotetext{
* To whom correspondence should be addressed. Phone: +52 (999) 9448479; e-mail: 1fcuevas@yahoo.com
} 


\section{Materials and methods}

\subsection{Chemicals and reagents}

The fresh, healthy, ripe black sapote fruits used were harvested at the Botanical Garden of Chapingo Autonomous University (UACH) in Merida, Yucatan, Mexico.

The standards used for the identifications were supplied by Aldrich (Steinheim, Germany) and Fluka (Buchs, Switzerland), while others were donated by Dallant (Barcelona, Spain). An $n$-alkane solution $\left(\mathrm{C}_{8}-\mathrm{C}_{32}\right)$ from Sigma-Aldrich (St. Louis, $\mathrm{MO}$ ) was employed to calculate the linear retention index (LRI) of each analyte. Dichloromethane was purchased from Merck (Darmstadt, Germany) and was previously redistilled and verified as pure in our lab.

\subsection{Isolation of volatile compounds by simultaneous distillation-solvent extraction}

Volatile compounds were isolated according to a previously reported method (PINO, 2012; Cuevas-Glory et al., 2012). Two hundred grams of sliced fruits were blended with $500 \mathrm{ml}$ of distilled water; $0.2 \mathrm{mg}$ of methyl nonanoate was added as internal standard, and the volatile compounds were isolated by means of SDE apparatus using $40 \mathrm{ml}$ of dichloromethane for 1 h. The extract was dried over anhydrous $\mathrm{Na}_{2} \mathrm{SO}_{4}$ and concentrated to $0.6 \mathrm{ml}$ in a KudernaDanish evaporator with a Vigreux column and then to $0.2 \mathrm{ml}$ with a gentle nitrogen stream. The recovery and repeatability of the extraction procedure was tested for certain compounds [2-butanone, benzaldehyde, limonene, $(E)$ - $\beta$-ocimene, $(E)$-cinnamaldehyde and methyl $(E)$ cinnamate]. A triplicate analysis was performed. The average recovery was $80 \%$, and the relative standard deviations were $<10 \%$. The concentrated extract was stored in a glass screw-top vial at $-20{ }^{\circ} \mathrm{C}$ until analysed. Three independent extractions were performed and each extract was injected twice into the GC-FID and GC-MS.

\subsection{GC-FID and GC-MS analysis}

A Perkin-Elmer Autosystem XL (Shelton, CT, USA) equipped with a $30 \mathrm{~m} \times 0.25 \mathrm{~mm} \times 0.25$ mm film thickness RTX-5MS (Restek, EE.UU.) fused-silica capillary column and with a flame ionization detector was used. Oven temperature was maintained at $50{ }^{\circ} \mathrm{C}$ for $2 \mathrm{~min}$ and then increased to $280{ }^{\circ} \mathrm{C}$ at $4{ }^{\circ} \mathrm{C} \mathrm{min}^{-1}$ and held for $10 \mathrm{~min}$. Carrier gas (helium) flow rate was $1 \mathrm{ml} \mathrm{min}{ }^{-1}$. The injection and detector temperatures were 240 and $250{ }^{\circ} \mathrm{C}$, respectively. The retention times of a series of straight-chain alkanes $\left(\mathrm{C}_{8}-\mathrm{C}_{32}\right)$ were used to calculate the retention indices for all identified compounds and for reference standards. Estimated concentrations for all compounds were made by GC peak area comparisons of the SDE extract components, with the area of a known quantity of internal standard. Concentrations were expressed as mg methyl nonanoate equivalents $/ \mathrm{kg}$ of fresh weight, response factors being taken as 1.0 for all compounds with reference to the internal standard, and a recovery factor of $80 \%$ was considered.

GC-MS analyses were performed on a Perkin-Elmer Clarus 500 gas chromatograph with a similar fused capillary column as in GC-FID. The temperature programme and carrier gas flow rate were the same as in GC-FID, EIMS electron energy, $70 \mathrm{eV}$; ion source and connecting parts temperature: $250{ }^{\circ} \mathrm{C}$. The acquisition was performed in scanning mode (mass range $\mathrm{m} / \mathrm{z} 35-400$ ). 
The volatile compounds were preliminarily identified by the use of NIST, Wiley, NBS, Adams 2001 and in-house Flavorlib libraries. Their identities were confirmed by comparison of their linear retention indices with those of reference standards or with published data (ADAMS, 2001).

\subsection{Odour detection threshold determination}

A previously described multiple paired comparison test was used (PinO \& MESA, 2006). Samples were prepared in capped, wide-mouthed, $50 \mathrm{ml}$ glass bottles. A group of 30-40 unscreened and untrained assessors was used for determining the odour thresholds. In each case, panels were replicated a sufficient number of times, so that a minimum of 100 responses were obtained for each concentration used in determining a particular threshold. The test involved presenting the assessors with several samples, along with an aqueous solution for reference. Each sample was compared in smell individually with the reference to determine whether a potential difference existed. Six samples were presented to each judge during each session. The first bottle was the reference and the next five coded bottles contained four different dilutions and an aqueous solution identical to the reference. The four dilutions were placed in order of increasing concentrations to prevent fatigue. The position of the aqueous solution coded sample among the different samples was arbitrarily changed from day to day. The statistical analyses for determining the odour detection threshold values involved calculating the concentration corresponding to $50 \%$ positive responses from the total judgments. The calculation was made from the linear regression of percentage detection against log concentration. The $95 \%$ confidence limit calculated for the threshold values was used as a measure of error. The relative standard deviations were lower than $6 \%$.

\section{Results and discussion}

All of the volatiles from black sapote, isolated by SDE with dichloromethane, were evaluated by three experts by smearing a drop of the extract onto a cardboard smelling strip as done by perfumers. After the evaporation of the solvent, all three experts agreed that the distillate evoked the characteristic odour of the fruit, thereby indicating that the method used for aroma isolation was appropriate.

A total of 32 volatiles were identified, representing $4.57 \mathrm{mg} \mathrm{kg}^{-1}$ in black sapote fruit (Table 1). In comparison with other tropical fruits, this represent a low level, e.g. $1.5 \mathrm{mg} \mathrm{kg}^{-1}$ in star apple (PINo et al., 2002), $12.8 \mu \mathrm{g} \mathrm{kg}^{-1}$ in papaya (PINO et al., 2003a), 240-332 $\mathrm{mg} \mathrm{kg}^{-1}$ in bullock's heart (PINo et al., 2003b), 18-123 mg kg-1 in mango (PINO et al., 2005), $6.5 \mathrm{mg}$ $\mathrm{kg}^{-1}$ in sapote (PINO et al., 2006) and $18.8 \mathrm{mg} \mathrm{kg}^{-1}$ in yellow sapote (PINO, 2010), determined by using the same isolation technique. The composition of the fruit included 9 terpenes, 11 ketones, 5 aldehydes, 4 alcohols, 2 esters and one paraffin, all of which were reported for the first time. The distribution of the chemical families according to the total volatile composition is shown in Fig. 1. Major compounds were $(Z)-\beta$-ocimene $(26.6 \%$ of the total volatile composition), (E)-cinnamaldehyde $(25.5 \%)$ and limonene $(17.0 \%)$. 
Table 1. Volatile compounds of black sapote fruit

\begin{tabular}{|c|c|c|c|}
\hline Compound & LRI & ID & $\begin{array}{c}\text { Concentration } \pm \\
\text { standard deviation } \\
\left(\mathrm{mg} \mathrm{kg}^{-1}\right)\end{array}$ \\
\hline 2-Butanone & 600 & $\mathrm{a}$ & $0.07 \pm 0.006$ \\
\hline 1-Butanol & 653 & $\mathrm{a}$ & $0.01 \pm 0.001$ \\
\hline 3-Methylbutanal & 656 & $\mathrm{a}$ & $0.05 \pm 0.001$ \\
\hline 2-Pentanone & 688 & $\mathrm{a}$ & $0.01 \pm 0.001$ \\
\hline 3-Pentanone & 703 & $\mathrm{a}$ & $\operatorname{tr}$ \\
\hline (Z)-2-Pentenol & 772 & $\mathrm{~b}$ & $0.05 \pm 0.002$ \\
\hline 3-Hexanone & 784 & $\mathrm{~b}$ & $0.03 \pm 0.001$ \\
\hline 2-Hexanone & 792 & $\mathrm{a}$ & $0.04 \pm 0.002$ \\
\hline 2-Furfural & 835 & $\mathrm{a}$ & $0.07 \pm 0.003$ \\
\hline 1-Hexanol & 870 & $\mathrm{a}$ & $0.05 \pm 0.002$ \\
\hline 3-Heptanone & 888 & $\mathrm{~b}$ & $0.07 \pm 0.007$ \\
\hline 2-Heptanone & 892 & $\mathrm{a}$ & $\operatorname{tr}$ \\
\hline Benzaldehyde & 962 & $\mathrm{a}$ & $0.04 \pm 0.002$ \\
\hline 1-Octen-3-one & 980 & $\mathrm{a}$ & $0.03 \pm 0.001$ \\
\hline$n$-Decane & 1000 & a & $0.04 \pm 0.001$ \\
\hline Limonene & 1029 & $\mathrm{a}$ & $0.78 \pm 0.05$ \\
\hline Benzyl alcohol & 1033 & $\mathrm{a}$ & $0.05 \pm 0.002$ \\
\hline (Z)- $\beta$-Ocimene & 1038 & $\mathrm{a}$ & $1.22 \pm 0.08$ \\
\hline 5-Nonanone & 1047 & $\mathrm{~b}$ & $0.05 \pm 0.002$ \\
\hline Acetophenone & 1065 & $\mathrm{a}$ & $0.03 \pm 0.001$ \\
\hline Linalool & 1098 & $\mathrm{a}$ & $0.04 \pm 0.002$ \\
\hline Methyl 2-methyloctanoate & 1158 & $\mathrm{~b}$ & $0.03 \pm 0.001$ \\
\hline$\alpha$-Terpineol & 1190 & a & $0.03 \pm 0.001$ \\
\hline (Z)-Cinnamaldehyde & 1219 & $\mathrm{a}$ & $0.01 \pm 0.001$ \\
\hline cis-Myrtanol & 1254 & $\mathrm{~b}$ & $\operatorname{tr}$ \\
\hline (E)-Cinnamaldehyde & 1271 & a & $1.16 \pm 0.07$ \\
\hline Neryl acetate & 1362 & a & $0.03 \pm 0.001$ \\
\hline Methyl (E)-cinnamate & 1379 & a & $0.34 \pm 0.03$ \\
\hline (Z)-Jasmone & 1394 & $\mathrm{a}$ & $0.09 \pm 0.008$ \\
\hline$\beta$-Caryophyllene & 1419 & $\mathrm{a}$ & $0.06 \pm 0.007$ \\
\hline$(Z, E)-\alpha$-Farnesene & 1491 & $\mathrm{a}$ & $0.04 \pm 0.002$ \\
\hline epi- $\alpha$-Cadinol & 1642 & $\mathrm{~b}$ & $0.06 \pm 0.003$ \\
\hline
\end{tabular}

tr: Lower than $0.01 \mathrm{mg} \mathrm{kg}^{-1}$; LRI: linear retention indices in RTX-5MS column; ID: identification; a: compound definitely identified (comparison of LRI and mass spectra with reference compound); b: by mass spectra data and retention index data from literature. 


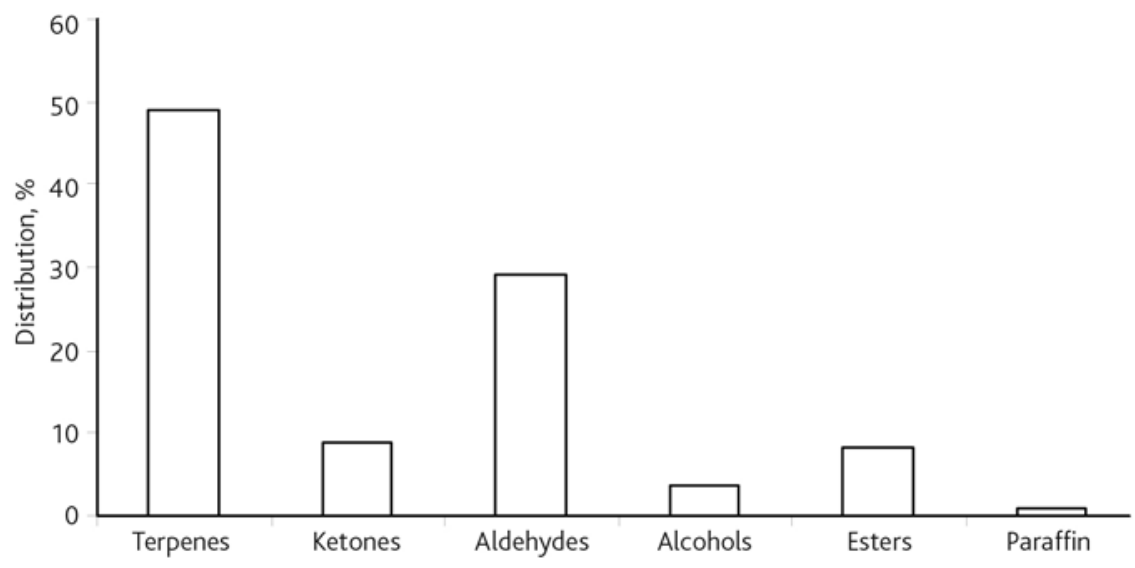

Fig. 1. Distribution of the chemical groups in the volatiles of black sapote fruit

It has been shown for a considerable number of foods that not all the volatiles present in a food are able to interact with human olfactory receptors. Instead, only a smaller number of the so-called key odorants is obviously detected by the human odorant receptors and, consequently, participate in the creation of the respective aroma impression in the brain (SCHIEBERLe, 1995). An approach to distinct odour-active volatiles from the bulk of odourless food volatiles is to correlate the concentrations of the individual odorants with the respective odour thresholds using the odour activity value (OAV) concept (SchIEBERLE, 1995). As summarized in Table 2, the results yielded seven aroma-active compounds with $\mathrm{OAV}>1$, which are arranged following their retention indices. By far the highest value was found for (E)-cinnamaldehyde with a characteristic warm-spicy-balsamic odour. Another important odour-active compound was 3-methylbutanal (fruity and malty odour), based on its higher OAVs (above 100). Other potentially important odorants obtained with the odour activity approach were limonene, $(Z)$ - $\beta$-ocimene, linalool, methyl $(E)$-cinnamate and $\beta$-caryophyllene.

Table 2. Aroma-active compounds identified in black sapote fruit

\begin{tabular}{lclc}
\hline Compound & $\begin{array}{c}\text { Odour threshold } \\
\left(\mu \mathrm{kg}^{-1}\right)\end{array}$ & Odour note $^{\mathrm{a}}$ & OAV $^{\mathrm{b}}$ \\
\hline 3-Methylbutanal & $0.2^{\mathrm{c}}$ & fruity, malty & 261 \\
Limonene & $10^{\mathrm{d}}$ & pungent green, citrus-like & 78 \\
$(Z)$ - $\beta$-Ocimene & $34^{\mathrm{c}}$ & warm-herbaceous, sweet-floral & 36 \\
Linalool & $6^{\mathrm{d}}$ & sweet, floral & 7 \\
$(E)-C i n n a m a l d e h y d e$ & $7^{\mathrm{c}}$ & warm-spicy-balsamic & 7759 \\
Methyl $(E)$-cinnamate & $191^{\mathrm{c}}$ & strawberry, honey & 2 \\
$\beta$-Caryophyllene & $64^{\mathrm{d}}$ & fresh, fruity & 1 \\
\hline
\end{tabular}

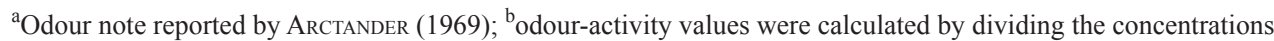
by the respective odour threshold; ${ }^{c}$ experimental; ${ }^{d}$ data taken from LefFingwell \& Assoc. (2011). 
To confirm the aroma contribution of these compounds, aroma extract dilution analysis studies and aroma recombination experiments warrant future study. However, the aromaactive compounds identified can already be suggested as indicators to assess the odour quality of black sapote fruit.

\section{Conclusions}

A total of 32 volatiles were detected, which comprised $4.57 \mathrm{mg} \mathrm{kg}^{-1}$ of black sapote fruit, included 9 terpene compounds, 11 ketones, 5 aldehydes, 4 alcohols, 2 esters and a paraffin. Major compounds were (Z)- $\beta$-ocimene $(26.6 \%$ of the total volatile composition), $(E)$ cinnamaldehyde $(25.5 \%)$ and limonene $(17.0 \%)$. Seven constituents were considered as aroma-active volatiles, from which the most important were $(E)$-cinnamaldehyde, 3-methylbutanal, limonene, (Z)- $\beta$-ocimene, linalool, methyl (E)-cinnamate and $\beta$-caryophyllene.

\section{References}

AdAms, R.P. (2001): Identification of essential oil components by gas chromatography/quadrupole mass spectroscopy. Allured Publishing Co., Carol Stream, IL, 456 pages.

Arctander, S. (1969): Perfume and flavour chemicals: Aroma chemicals, Steffen Arctander Publications, Las Vegas.

Cuevas-Glory, L., Ortiz-Vazquez, E., Sauri-Duch, E. \& Pino, J. (2013): Characterization of aroma-active compounds in sugar apple (Annona squamosa L.). Acta Alimentaria, 42, 102-108.

Ledesma, N. \& CAmpBell, J. (2001): Reseña histórica, cultivares y propagación del zapote prieto (Diospyros digyna Jacq.) en el Sur de la Florida. (Historical review, cultivars and propagation of black sapote (Diospyros digyna Jacq.) in South Florida.) Proc. Interamer. Hortic., 45, 12-14.

LEFFINGWELL \& Assoc. (2011): Odor and flavor detection thresholds in water (in parts per billion). Available from: http://www.leffingwell.com/odorthre.htm. Accessed Sept 18, 2011.

Martín, F., Campbell, C.W. \& Ruberté, R.M. (1987): Perennial edible fruits of the tropics. An inventory. Agricultural Research Service. USDA. Agriculture Handbook No. 642. 252 pages.

Miller, W.R., Sharp, J.L. \& Baldwin, E. (1998): Quality of irradiated and nonirradiated black sapote (Diospyros digyna Jacq.) after storage and ripening. Agric. Res. Service TEKTRAN, 110, 215-218.

Morton, J.F. (1987): Fruits of warm climates. Miami, Fl., pp. 416-418.

PInO, J. (2010): Volatile compounds from fruits of Pouteria campechiana (Kunth) Baehni. J. Essent. Oil Bearing$P l ., 13,326-330$.

PINO, J. (2012): Odour-active compounds in mango (Mangifera indica L. cv. Corazón). Int. J. Fd Sci. Technol., 47, 1944-1950.

Pino, J. \& MesA, J. (2006): Contribution of volatile compounds to mango (Mangifera indica L.) aroma. Flavour Fragr. J., 21, 214-221.

Pino, J., Marbot, R. \& Rosado, A. (2002): Volatile constituents of star apple (Chrysophyllum cainito L.) from Cuba. Flavour Fragr. J., 17, 401-403.

Pino, J., Almora, K. \& Marbot, R. (2003a): Volatile components of papaya (Carica papaya L., Maradol Variety) fruit. Flavour Fragr. J., 18, 492-496.

Pino, J., Marbot, R. \& Fuentes, V. (2003b): Characterization of volatiles in bullock`s heart (Annona reticulata L.) fruit. J. Agric. Fd Chem., 51, 3836-3839.

Pino, J., Mesa, J., Muñoz, Y., Martí, M.P. \& Marbot, R. (2005): Volatile components from mango (Mangifera indica L.) cultivars. J. Agric. Fd Chem., 53, 2213-2223.

Pino, J., Marbot, R., Sauri, E. \& ZumÁrraga, C. (2006): Volatile components of sapote (Pouteria sapota (Jacq.) H. E. Moore et Stern) fruit. J. Essent. Oil Res., 18, 22-23.

SAGARPA (2001): Anuario estadistico de la producción agrícola. (Statistical yearbook of the agricultural production.) Secretaría de Agricultura, Ganadería, Desarrollo Rural, Pesca y Alimentación. Mexico. www. sagarpa.com.gob (July 2003).

Schieberle, P. (1995): Recent developments in methods for analysis of flavor compounds and their precursors. -in: GoAnKar, A. (Ed.) Characterization of food: emerging methods. Elsevier, Amsterdam, The Netherlands; pp. $403-431$. 